\title{
Prediksi Daerah Rawan Longsor Pada Kawasan Pengembangan Jalan Nasional Pulau Sanana di Maluku Utara
}

\author{
Prediction of Vulnerable Area to Landslide in National Road Development Area of Sanana Island \\ in North Maluku
}

\section{Pieter J. Kunu* dan Marcus Luhukay}

\author{
Jurusan Budidaya Pertanian, Fakultas Pertanian, Universitas Pattimura, Jl. Ir. M. Putuhena, Kampus Poka, Ambon \\ 97233 \\ *Penulis Korespondensi: E-mail: pieterkunu@gmail.com
}

\begin{abstract}
Research has been conducted with the aim of mapping a potential landslide of soil that is alleged to be happening on a national road development area on the island of North Maluku Sanana island because in some locations excavations or cutting slope were conducted for build trails. Research was done by survey method, by analysis of land as well as the analysis of soil samples in the laboratory against some physical-chemical soil parameters to predict the potential for landslide of soil. The results showed that in the developed area of national roads, there were some points or locations with the potential landslide. However, by cutting slope of landslide the potential became greater, things which would be very threatening road users on the sections of the road that passes through the hilly and mountainous regions. The cutting slopes have been disturbing the equilibrium slope stability or lower slopes so the landslide is easy to happen. Mitigation efforts can be done by building a retaining structure at the foot of the slopes, the angle of the cutting slope made slightly sloping and in the upper part land use should be preserved and enriched with plant conservation to improve the stability of slopes.
\end{abstract}

Keywords: a potential avalanche of soil, national road, slope stability

\section{ABSTRAK}

Penelitian telah dilakukan dengan tujuan untuk memetakan potensi longsoran tanah yang diduga akan terjadi pada kawasan pengembangan jalan nasional di Pulau Sanana Maluku Utara karena di beberapa lokasi dilakukan penggalian atau pemotongan lereng untuk membangun jalur jalan. Penelitian dilakukan dengan metode survey dengan analisis lahan serta analisis sampel tanah di laboratorium terhadap beberapa parameter fisik-kimia tanah untuk memprediksi potensi longsoran tanah. Hasil penelitian menunjukkan bahwa pada kawasan ruas jalan nasional yang dikembangkan terdapat beberapa titik atau lokasi dengan potensi longsoran tergolong sedang. Namun dengan adanya pemotongan lereng maka potensi longsoran menjadi semakin besar, hal mana akan sangat mengancam pengguna jalan di ruas-ruas jalan yang melewati kawasan berbukit dan bergunung. Pemotongan lereng telah mengganggu keseimbangan lereng atau menurunkan stabilitas lereng sehingga longsoran mudah terjadi. Upaya mitigasi dapat dilakukan dengan membangun struktur penahan di kaki lereng, sudut pemotongan lereng dibuat landai dan penggunaan lahan di bagian atas lereng harus dipertahankan dan diperkayadengan tanaman konservasi untuk meningkatkan stabilitas lereng yang sudah terganggu.

Kata kunci: jalan nasional, potensi longsoran tanah, stabilitas lereng

\section{PENDAHULUAN}

Meningkatnya ekonomi suatu wilayah sangat ditentukan antara lain oleh factor aksesibilitas antar daerah melalui dibukanya dan dikembangkannya infratsruktur jalan atau prasarana jalan penghubung antar daerah-daerah yang terisolasi karena memiliki peran yang sangat vital untuk mendukung eknomi social suatu masyarakat. Menurut Warsilan dan Noor (2015), pembangunan infrastruktur akan dapat berdampak pada pertumbuhan ekonomi, baik secara langsung maupun tidak langsung. Infrastruktur sendiri merupakan prasyarat bagi sektor-sektor lain untuk berkembang dan juga sebagai sarana penciptaan hubungan antara satu dengan yang lainnya. Pemberdayaan sumber daya untuk membangun infrastruktur akan memicu proses ekonomi sehingga menimbulkan penggandaan dampak ekonomi maupun sosial (Novi et al., 2014; Setiadi, 2006).

Kegiatan pengembangan jalan nasional di Pulau Sanana telah dilakukan sejak beberapa tahun yang lalu. 
Jalan yang dikembangkan tidak berada pada kawasan lindung kecuali ruas jalan Sanana-Pohea yang melewati areal hutan mangrove yang terpaksa direklamasi karena tidak ada alternative jalur jalan yang lain untuk dibuka. Kondisi topografi yang berbukit dan bergunung yang menjadi ciri pulau-pulau kecil menyebabkan pembukaan ruas jalan baru berpotensi melewati kawasan bukit dan gunung yang menyebabkan terjadinya pemotongan lereng-lereng bukit dan gunung yang mengganggu stabilitas lereng sehingga memungkinkan terjadinya longsoran tanah.

Curah hujan dengan durasi yang lama disertai intensitas yang tinggi merupakan salah satu faktor penyebab terjadinya bencana tanah longsor. Korban jiwa manusia dan kerugian ekonomi akibat tanah longsor mengilustrasikan bahwa betapa besar upaya mitigasi yang harus dilakukan untuk mengantisipasi kelongsoran pada lereng yang kritis, dimana air memberikan kontribusi terhadap kejadian longsoran tanah. Selain itu, gangguan terhadap stabilitas lereng dapat terjadi jika tahanan geser tanah tidak mampu mengirnbangi gaya-gaya luar yang menyebabkan gelincir pada bidang longsor (Theresia et al., 2011).

Longsoran tanah adalah perpindahan masa tanah secara alami dan dalam waktu singkat dengan volume yang relative besar (Sukisno dan Muin, 2012). Sedangkan menurut Sukresno et al. (2004), tanah longsor, secara umum diartikan gerakan masa tanah, batuan dan air yang menyerupai lumpur serta mengandung kayu-pepohonan yang ikut terseret menggelincir ke bawah menuruni kemiringan lahan. Di Indonesia, termasuk di Maluku Utara, longsoran yang terjadi dapat berbentuk luncuran atau guguran. Luncuran adalah pergerakan massa tanah dalam volume yang besar dari atas lereng ke bawah oleh adanya lapisan atau bidang luncur dimana massa tanah di atasnya telah jenuh air atau stabilitas lereng terganggu. Sedangkan guguran adalah pergerakan massa tanah dan atau batuan yang jatuh bebas dari atas lereng curam.

Berdasarkan fakta-fakta di atas, dirasa perlu dilakukan penelitian di ruas-ruas jalan nasional di Pulau Sanana, untuk menetapkan kawasan rawan longsoran agar proses mitigasi dapat segera dilaksanakan.

\section{METODE PENELITIAN}

\section{Jenis Penelitian}

Penelitian ini merupakan penelitian survey yaitu pengamatan dilakukan langsung di lapangan dengan melakukan identifikasi dan pengumpulan data primer dan desk analysis serta analisis laboratorium terhadap sampel tanah yang dikumpulkan di lapangan mewakili jenis tanah yang ada.

\section{Tempat dan Waktu penelitian}

Tempat pelaksanaan penelitian yaitu Pulau Sanana dilaksanakan pada bulan Agustus-Oktober 2017.

\section{Alat dan bahan}

Alat yang digunakan adalah GPS, abney level, soil auger, pisau lapang, camera, alat tulis, dan altimeter. Bahan yang digunakan adalahair dari perlindungan mata air ditiap daerah pengambilan sampel.

\section{Ruang lingkup penelitian}

Maluku sebagai salah satu provinsi kepulauan, terdiri atas lebih dari 1000 pulau yang didominasi oleh pulau-pulau kecil. Kondisi pulau yang kecil umumnya didominasi oleh topografi yang umum berupa bukit dan gunung sehingga pengembalan jalan kedang melewati kawasan berlereng sehingga untuk memenuhi kebutuhan pembangunan jalur jalan, kadangkala lerenglereng harus dipotong. Situasi akan menciptakan stabilitas lereng terganggu sehingga berpotensi terjadi longsoran.

Untuk mengantisipasi terjadinya longsoran yang dapat membahayakan pengguna jalan raya nantinya, kajian longsoran dan sebarannya di sepanjang jalan tersebut perlu dilakukan dengan melakukan survey, pengumpulan data lahan dan sampel tanah untuk analisis laboratorium dalam rangka pemetaan kawasan yang yang berpotensi terjadi longsoran.

\section{Prosedur Penelitian}

Penilaian bahaya longsor pada lokasi kajian didasarkan pada kriteria pendugaan longsoran berdasarkan nilai scoring yang dikemukakan oleh Permentan No. 47/Permentan/OT.140/10/2006.

\section{Pengukuran parameter}

Sesuai Permentan No. 47/Permentan/OT.140/ 10/2006 maka parameter yang harus diukur adalah curah hujan, kandungan liat mineral tipe 2:1, dan laju infiltrasi. Parameter lain dikumpulkan dari studi literatur. Data curah hujan diperoleh dari stasiun klimatologi terdekat dengan lokasi penelitian; liat mineral 2:1 diketahui melalui analogi hasil penelitian sebelumnya. Untuk laju infiltrasi akan diukur melalui pengambilan sampel tanah utuh kemudian dianalisis di laboratorium. Sedangkan kedalaman lapisan kedap akan diukur melalui pengamatan tanah di lapangan.

\section{Pengukuran lingkungan fisik/Kondisi Lahan}

Pengukuran lingkungan fisik terkait ketinggian tempat, kemiringan lahan (kelerengan), penggunaan lahan dan jenis tanah, dilakukan di lapangan.

\section{HASIL DAN PEMBAHASAN}

\section{Penggunaan Lahan dan Alih Funsgi Lahan}

Hasil observasi di lapangan ditemukan bahwa ruas-ruas jalan nasional yang dibangun (lintasan 
Sanana-Pohea, Pohea-Malbufa, dan Sanana-Manaf) merupakan ruas jalan yang berada di kawasan pesisir Pulau Sanana dengan fisiografi dataran hingga berbukit. Penggunaan lahan yang umum tersebar adalah merupakan vegetasi pesisir dan kebun campuran milik masyarakat setempat. Jenis vegetasi yang ditemukan berupa tanaman kelapa yang ada dalam kebun campuran milik masyarakat, dan sebagian juga ditanami di areal yang ditumbuhi Semak belukar, kayu besi, Jati, Pule, Kayu santan, Sunggah sunggah, Solasi bangke, dan Hutan mangrove.

Penggunaan lahan di sekitar jalan yang dikembangkan berupa pemukiman, daerah wisata pantai, hutan sekunder, hutan mangrove, semak belukar, area budidaya pertanian (ladang/tegalan), area budidaya perikanan (di Bajo dan Manaf), perkebunan rakyat (cengkeh, kelapa, mete), jaringan listrik, fasilitas umum (jembatan, pelabuhan dan dermaga ferry, pelabuhan PPI, pelabuhan lokal).

Ruas-ruas jalan yang dibangun melewati seluruh bentuk penggunaan lahan yang ada, dan khusus untuk ruas jalan Sanana-Pohea sebagian kecil hutan mangrove dikonversi dengan reklamasi. Sementara ruas jalan yang melewati kebun campuran milik masyarakat setempat dilakukan pembebasan lahan dengan ganti rugi yang telah disepakati.

\section{Jaringan Jalan}

Pada dasarnya jalur jalan yang sudah ada hanya ada di kawasan Kota Sanana; sementara pada ruas jalan
Sanana-Pohea dan Pohea-Malbufa terdapat beberapa jalan akses ke lokasi TPA, dermaga ferry penyeberangan dan pelabuhan perikanan (PPI).

\section{Fisiografi}

Secara umum fisiografi pada lokasi kajian terdiri dari dataran, perbukitan dan bergunung. Ruas jalan Sanana-Manaf mendominasi fisiografi dataran di tepi pantai pada kelerengan antara $0-5 \%$ (datarlandai/berombak). Ruas jalan Sanana-Polnea dan Polnea-Malbufa berada pada fisografi dataran dan perbukitan rendah dengan kelerengan antara 0-25\% (datar-bergelombang).

Gambar 1-4 menyajikan hasil pemetaan kondisi topografi lokasi penelitian.

\section{Iklim}

Wilayah Kabupaten Kepulauan Sula memiliki tipe iklim tropis yang umumnya dipengaruhi oleh musim, yaitu musim Barat atau Utara dan Musim Timur atau Tenggara.Musim Timurberlangsung dari bulan Juni-Agustus, Musim Barat berlangsung dari bulan Desember hingga Pebruari, Musim pancaroba 1 berlangsung dari Maret-Mei, dan Pancaroba 2 berlangsung dari September-November. Secara keseluruhan wilayah Sanana memiliki 5 bulan kering dan 7 bulan basah, sehingga tipe iklim daerah ini menurut klasifikasi Schmit-Ferguson adalah tipe B (rata rata curah hujan tahunan $1.720 \mathrm{~mm}$ ).

Tabel 1. Hubungan Skor Biofisik Lahan Dengan Kepekaan Lahan Terhadap Longsor

\begin{tabular}{|c|c|c|c|c|c|c|}
\hline Faktor Fisik Lahan & Nilai & Skor & Nilai & Skor & Nilai & Skor \\
\hline Curah Hujan (mm) & $<1500$ & 1 & $1500-2500$ & 3 & $>2500$ & 5 \\
\hline Bahan Induk & Bt. vulkanik & 1 & Bt. metamorfik & 2 & Bt. sedimen & 3 \\
\hline Lereng $(\%)$ & $<25$ & 1 & $25-40$ & 3 & $>40$ & 5 \\
\hline Kandungan Liat 2:1 & Rendah & 1 & Sedang & 2 & Tinggi & 3 \\
\hline Laju infiltrasi & Lambat & 1 & Sedang & 2 & Cepat & 3 \\
\hline Kedalaman lapisan kedap air (cm) & $>100$ & 1 & $50-100$ & 2 & $<50$ & 3 \\
\hline
\end{tabular}

Keterangan: Nilai skor 6-10: kepekaan terhadap longsor rendah; nilai skor 11-25: kepekaan terhadap longsor sedang; nilai skor 1622: kepekaan terhadap longsor tinggi. Sumber: Permentan No. 47/Permentan/OT.140/10/2006

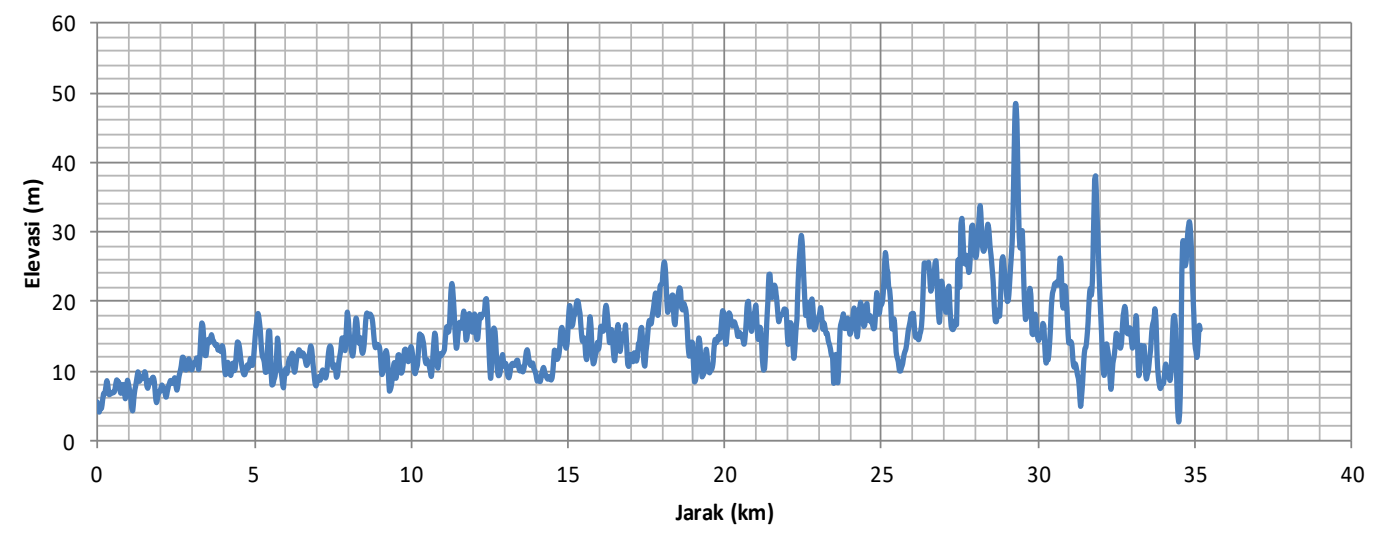

Gambar 1. Profil Elevasi Ruas Jalan Sanana Manaf (31 km) 


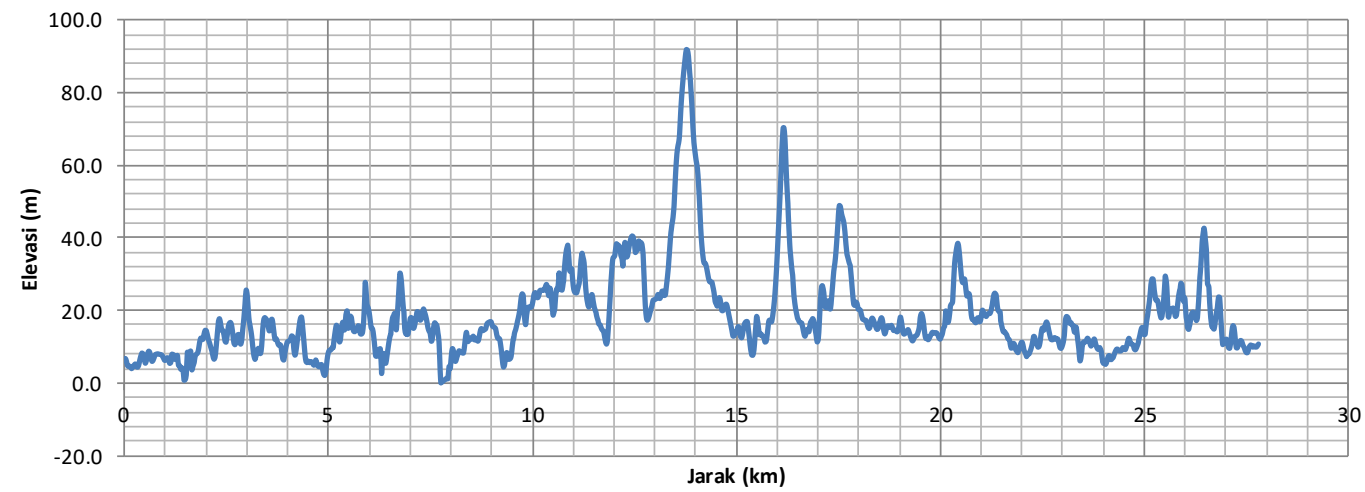

Gambar 2. Profil Elevasi pada Ruas Jalan Sanana Malbufa (25,05 km)

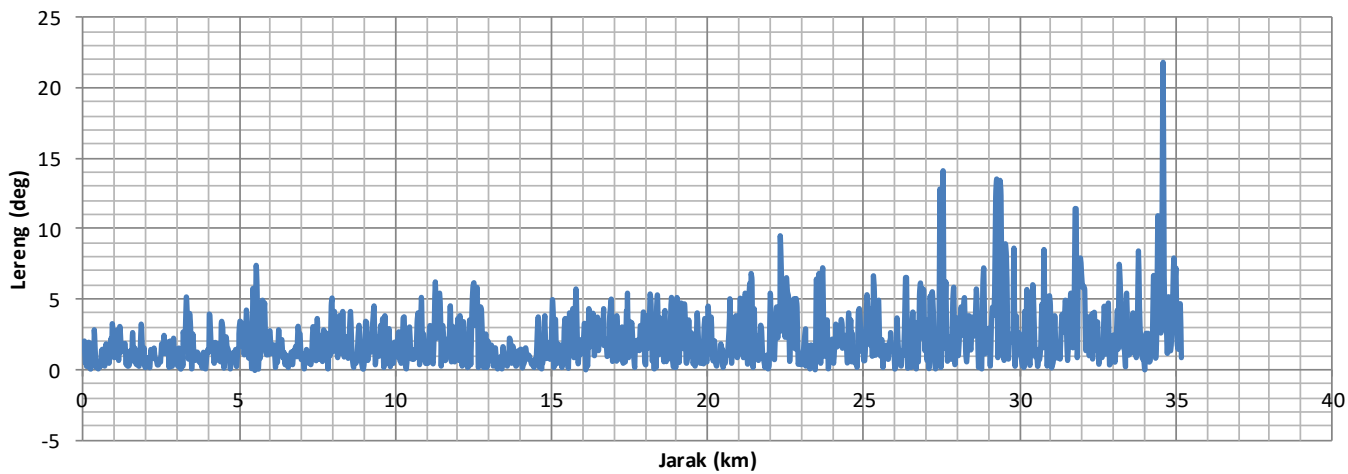

Gambar 3. Profil Lereng pada Ruas Jalan Sanana Manaf (31 km)

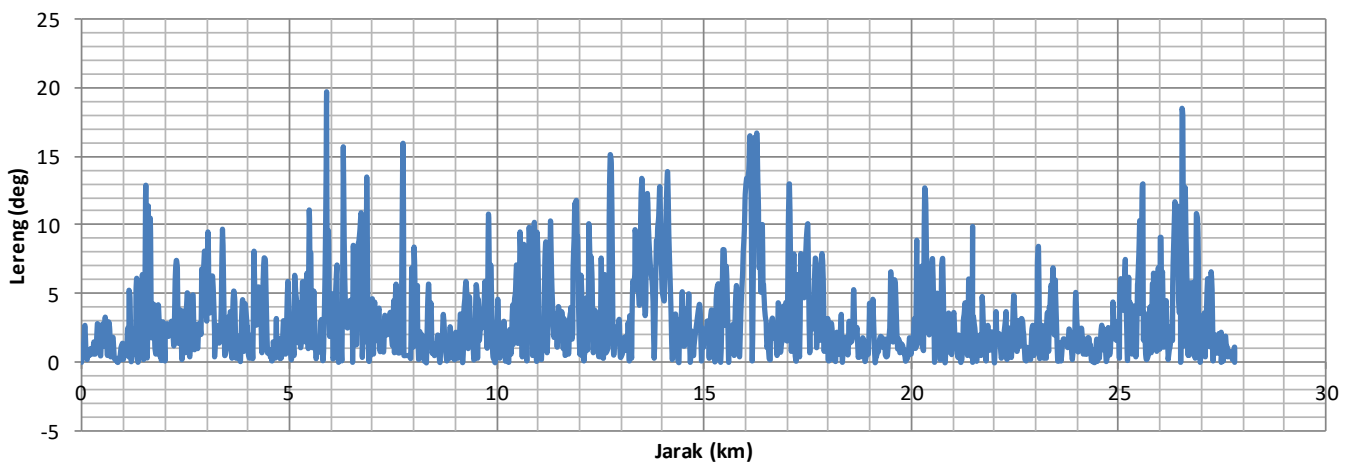

Gambar 4. Profil Lereng pada Ruas Jalan Sanana Malbufa (25,05 km).

\section{Curah Hujan dan Hari Hujan}

Hasil analisis data curah hujan lima tahun terakhir menunjukkan bahwa curah hujan di Wilayah Sanana berfluktuasi menurut musim. Puncak curah hujan sepanjang tahun terjadi pada bulan Juni dan Juli. Ada kecenderungan terjadi penurunan curah hujan tahunan sejak tahun 2011 dengan pola linier. Tahun 2011 terjadi puncak curah hujan yaitu 2538,8 mm dan pada tahun 2014 konsentrasi Curah Hujan tahunan mencapai nilai terendah yaitu $1592,3 \mathrm{~mm}$. Secara musiman, puncak konsentrasi curah hujan terjadi pada musim Timur (Juni dan Juli) sepanjang tahun dengan rata rata curah hujan kerkisar 302,8-342,4 mm dan curah hujan maksimum berkisar 533-588,1 mm.

Pola curah hujan demikian berindikasi bahwa pada bulan Mei-Agustus, wilayah daratan pesisir timur dan barat pulau Sanana akan menima suplay air hujan dalam jumlah besar, yang memungkinkan terjadinya runoff pada semua sistem sungai sepanjang wilayah DAS. Pada bulan Juni dan Agustus, potensi banjir dapat terjadi sepanjang ruas jalan yang dilalui sungai sungai. Hal ini akan berdampak pada kestabilan jembatan dan stabilitas beton jalan sekitar daerah aliran sungai. Selain itu potensi genangan juga sangat mungkin terjadi pada ruas jalan berelevasi rendah dengan topografi cekung, potensi erosi dan longsor tebing dapat juga terjadi pada sejumlah titik terutama pada lintasan jalan yang memotong topografi berbukit di wilayah PoheaMalbufa-Fokalik. Pada ruas jalan Sanana-Manaf, potensi erosi dan longsor tebing perbukitan sangat kecil, tetapi pada ruas jalan yang melintasi tepi tebing terjal pantai (sea cliff), sangat berpotensi terjadi erosi tebing walaupun tidak terjadi banjir dan genangan selama musim hujan. 

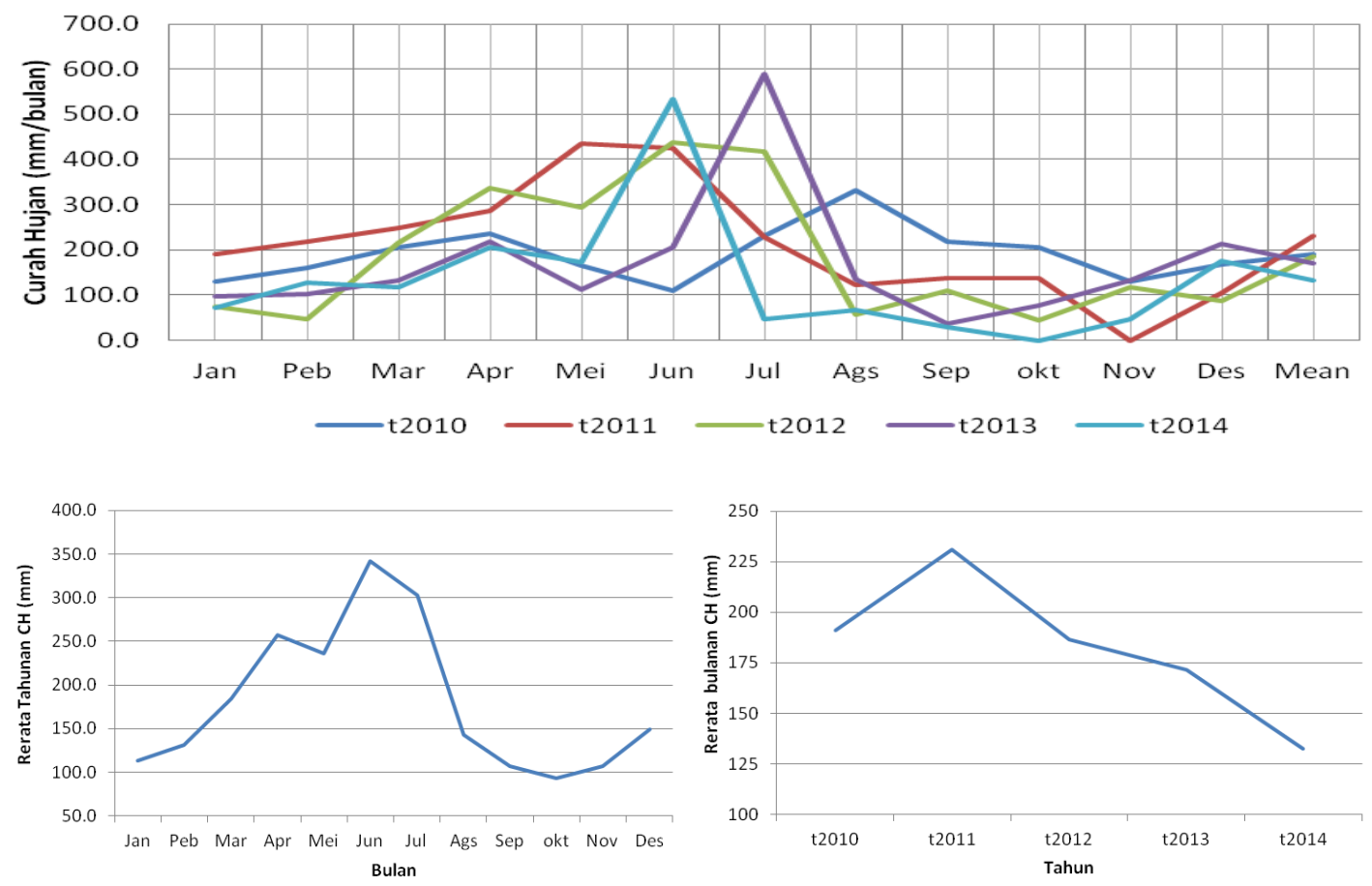

Gambar 5. Pola Curah Hujan Bulanan di Wilayah Sanana Tahun 2010-2014

\section{Bahan Induk dan Jenis Tanah}

Bahan induk pembentuk tanah pada lokasi studi terdiri atas bahan endapan/alluvium (endapan pantai dan endapan sungai) serta bahan lepas (loss material). Berdasarkan hasil identifikasi karakter tanah pada pengamatan lapangan untuk ruas jalan Sanana-Manaf, Sanana-Polnea dan Polnea-Matufa ditemukan satuan tanah Aquent (Gleisol), Psamment (Regosol), Fluvent (Aluvial) dan Udept (Kambisol). Tanah Aquent (Gleisol) ditemukan pada lokasi hutan mangrove, tanah Psamment (Regosol) ditemukan di lokasi sekitar tepi pantai, tanah Fluvent (Aluvial) ditemukan di sekitar daerah aliran sungai serta tanah Udept (Kambisol) ditemukan pada daerah berbukit.

Tanah Aquent (Gleisol) dengan ciri selalu tergenang (tergenang dalam waktu lama), tanah Psamment (Regosol) dengan ciri didominasi oleh tekstur pasir, tanah Fluvent (Aluvial) dicirikan oleh pengendapan berulang dan tanah Udept (Kambisol) dicirikan oleh adanya bahan induk melapuk.

\section{Infiltrasi dan Permeabilitas Tanah}

Hasil analisis infiltrasi dan permeabilitas tanah disajikan pada Table 6 .

Tabel 2. Deskripsi Tanah Regosol

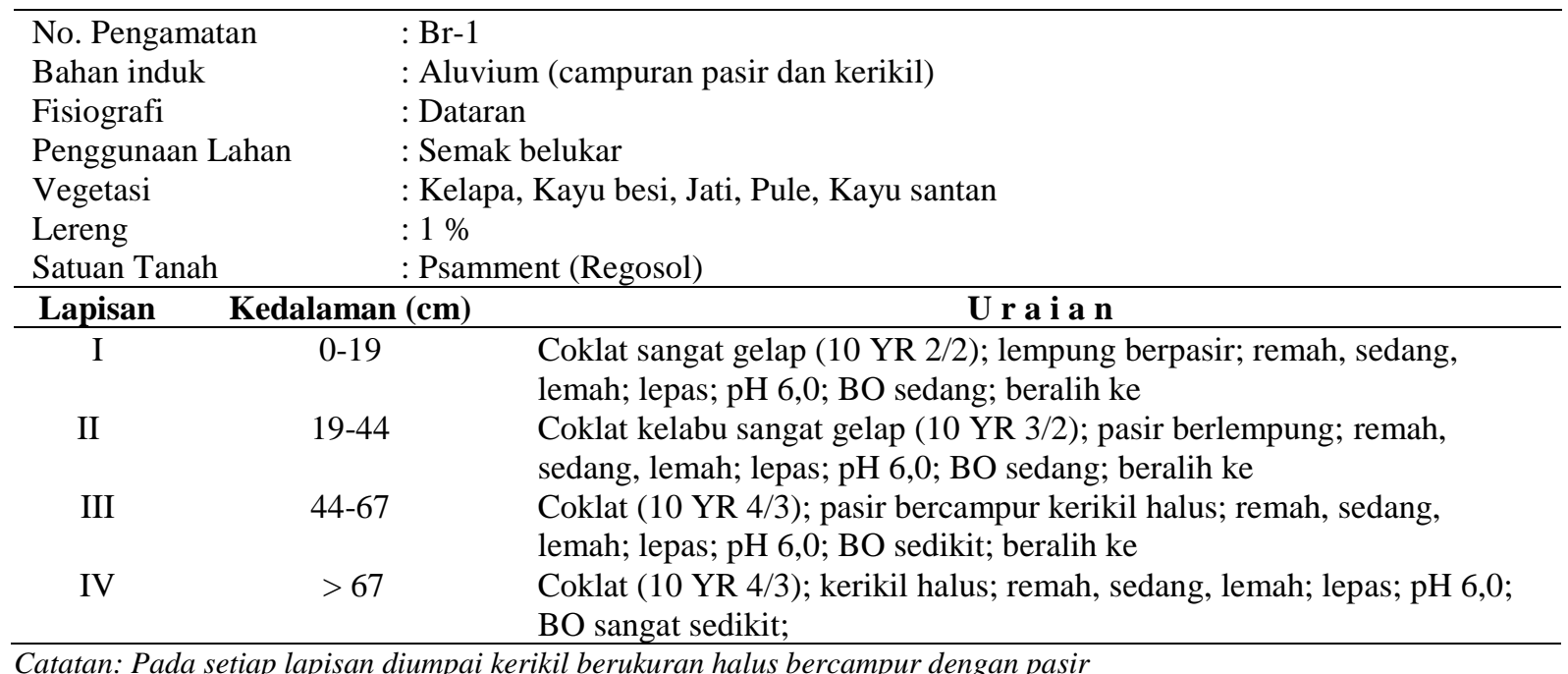

Catatan: Pada setiap lapisan diumpai kerikil berukuran halus bercampur dengan pasir 
Tabel 3. Deskripsi Tanah Aluvial

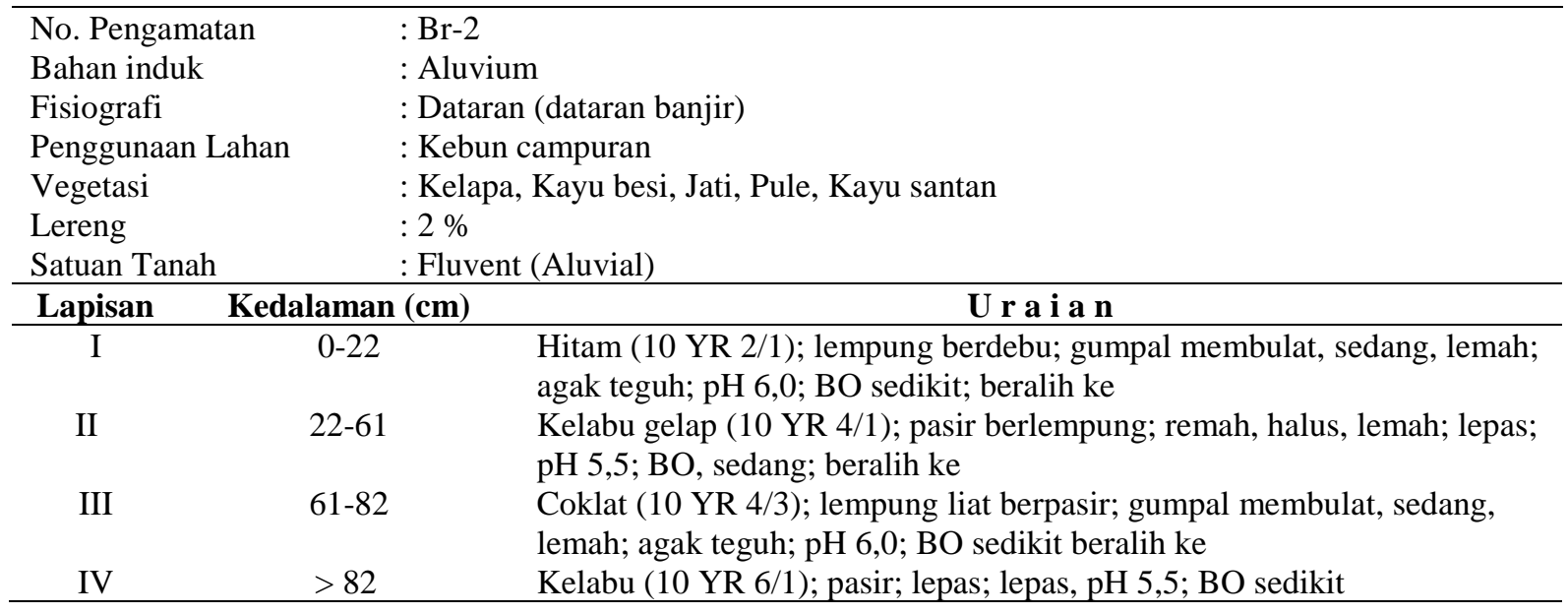

Tabel 4. Deskripsi Tanah Kambisol

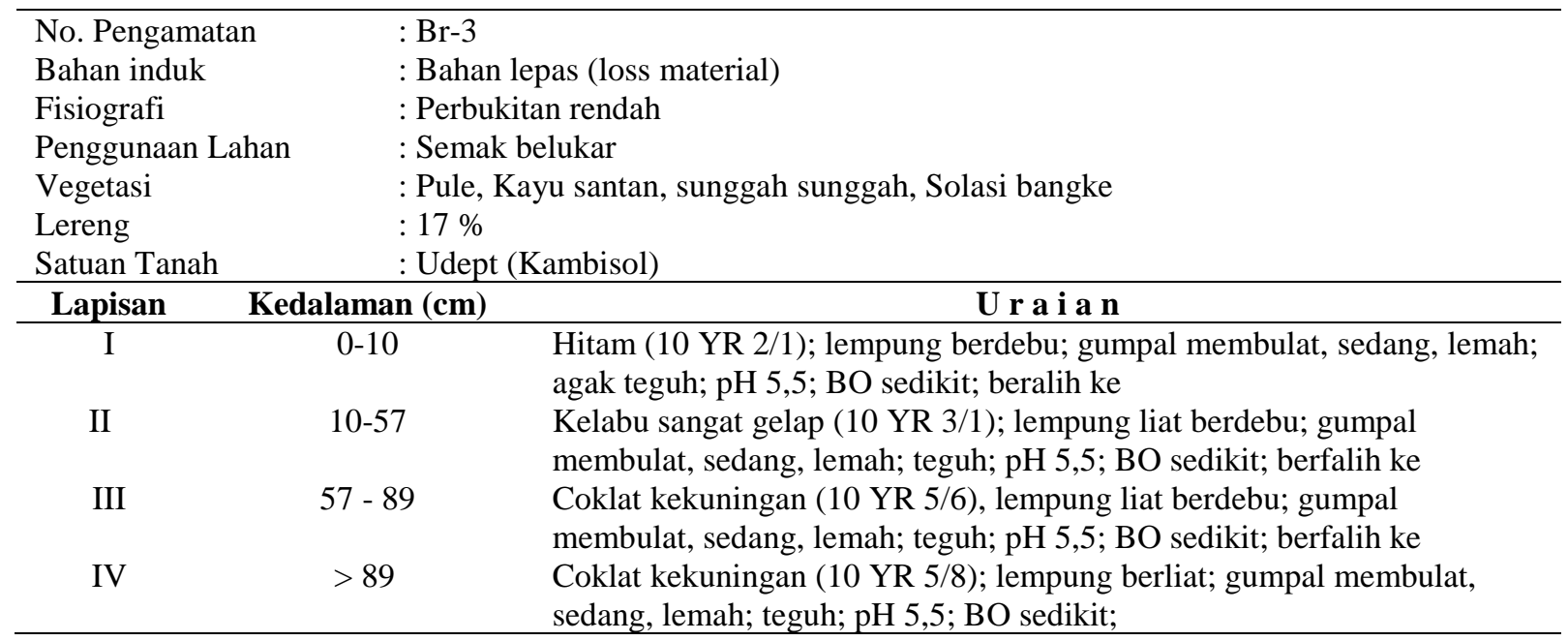

Tabel 5. Deskripsi Tanah Gleisol

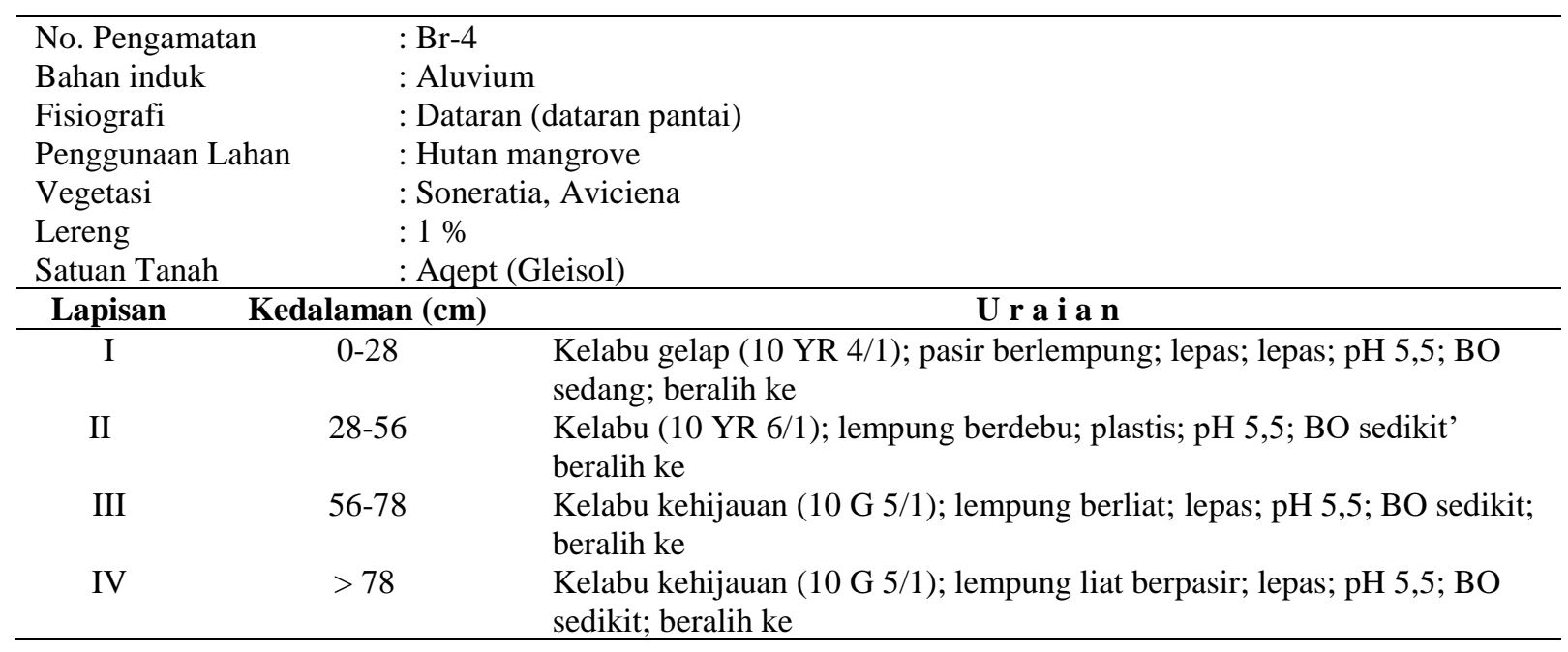


Tabel 6. Kelas Permeabilitas dan Kapasitas Infiltrasi

\begin{tabular}{ccccc}
\hline No. Ring & Kode & Permeabilitas (cm/jam) & Kelas & Laju Infiltrasi \\
\hline 1 & R1 & 4.03 & SEDANG & Sangat Cepat \\
2 & R2 & 3.76 & SEDANG & Sangat Cepat \\
3 & R3 & 4.06 & SEDANG & Sangat Cepat \\
\hline
\end{tabular}

Sumber: Laboratorium Tanah Fakultas Pertanian Unpatti (2016)

\section{Erosi dan Longsoran}

Pada ruas jalan Sanana-Manaf, erosi yang terjadi umunya erosi permukaan yang ringan. Hal ini disebabkan karena ruas jalan berada pada lokasi yang relative datar sedangkan erosi yang terjadi pada Ruas jalan Sanana-Pohea dan Pohea-Malbufa adalah erosi lembar (ada indikator pedestal).

Ruas jalan Sanana-Manaf, Sanana-Polnea dan Polnea-Malbufa memiliki tingkat kerawanan terhadap bahaya longsor antara rendah-sedang dengan jenis longsor guguran dan peluncuran. Bahaya longsor guguran sangat rentan terjadi pada ruas jalan SananaManaf karena pada ruas jalan ini banyak ditemukan tebing-tebing batu, sedangkan jenis longsor peluncuran sangat rentan terjadi pada ruas jalan Sanana-Polnea dan Polnea Matufa.

Selain bahaya longsor, khusus untuk ruas jalan Sanana-Manaf juga rawan terhadap abrasi pantai karena kedudukan jalan berdekatan dengan garis pantai.

Tabel 7. Ruas Jalan Sanana-Manaf (31 km)

\begin{tabular}{|c|c|c|c|c|c|c|c|}
\hline \multirow{2}{*}{ No } & \multirow{2}{*}{ Koordinat } & \multirow{2}{*}{ Tanah } & \multicolumn{2}{|r|}{ Lereng } & \multirow{2}{*}{ Fisiografi } & \multirow{2}{*}{ Erosi } & \multirow{2}{*}{ Longsor } \\
\hline & & & $\%$ & Panjang (m) & & & \\
\hline 1 & $\begin{array}{l}\mathrm{S}=02^{\circ} 20,091^{\prime} \\
\mathrm{E}=126^{\circ} 01,961^{\prime}\end{array}$ & $\begin{array}{c}\text { Psamment } \\
\text { (Regosol) }\end{array}$ & 1 & $>50$ & Dataran & Permukaan & Ringan \\
\hline 2 & & $\begin{array}{l}\text { Fluvent } \\
\text { (Aluvial) }\end{array}$ & 3 & $>50$ & Dataran & Permukaan & Ringan \\
\hline
\end{tabular}

Tabel 8. Ruas Jalan Sanana-Polnea (12,05 km)

\begin{tabular}{|c|c|c|c|c|c|c|c|}
\hline \multirow{2}{*}{ No. } & \multirow{2}{*}{ Koordinat } & \multirow{2}{*}{ Tanah } & \multicolumn{2}{|r|}{ Lereng } & \multirow{2}{*}{ Fisiografi } & \multirow{2}{*}{ Erosi } & \multirow{2}{*}{ Longsor } \\
\hline & & & $\%$ & Panjang (m) & & & \\
\hline 1 & & $\begin{array}{l}\text { Fluvent } \\
\text { (Aluvial) }\end{array}$ & 2 & $>50$ & Dataran & Permukaan & Ringan \\
\hline 2 & $\begin{array}{l}\mathrm{S}=01^{\circ} 59,435^{\prime} \\
\mathrm{E}=125^{\circ} 57,217^{\prime}\end{array}$ & $\begin{array}{c}\text { Udept } \\
\text { (Kambisol) }\end{array}$ & +22 & 50 & Perbukitan & Lembar & Sedang \\
\hline
\end{tabular}

Tabel 9. Ruas Jalan Polnea-Matufa (13 km)

\begin{tabular}{|c|c|c|c|c|c|c|c|}
\hline \multirow{2}{*}{ No. } & \multirow{2}{*}{ Koordinat } & \multirow{2}{*}{ Tanah } & \multicolumn{2}{|c|}{ Lereng } & \multirow{2}{*}{ Fisiografi } & \multirow{2}{*}{ Erosi } & \multirow{2}{*}{ Longsor } \\
\hline & & & $\%$ & Panjang $(\mathrm{m})$ & & & \\
\hline 1 & $\begin{array}{l}\mathrm{S}=01^{\circ} 59,046^{\prime} \\
\mathrm{E}=125^{\circ} 55,371^{\prime}\end{array}$ & $\begin{array}{c}\text { Udept } \\
\text { (Kambisol) }\end{array}$ & $\begin{array}{l}+17 \\
-15 \\
\end{array}$ & 70 & Perbukitan & Lembar & Sedang \\
\hline 2 & $\begin{array}{l}\mathrm{S}=01^{\circ} 58,995^{\prime} \\
\mathrm{E}=125^{\circ} 54,902^{\prime}\end{array}$ & $\begin{array}{c}\text { Udept } \\
\text { (Kambisol) }\end{array}$ & $\begin{array}{l}+25 \\
-22 \\
\end{array}$ & 50 & Perbukitan & Lembar & Sedang \\
\hline 3 & $\begin{array}{l}\mathrm{S}=01^{\circ} 59,042^{\prime} \\
\mathrm{E}=125^{\circ} 54,591\end{array}$ & $\begin{array}{c}\text { Udept } \\
\text { (Kambisol) }\end{array}$ & 10 & 20 & Perbukitan & Lembar & Sedang \\
\hline 4 & $\begin{array}{l}\mathrm{S}=02^{\circ} 00,403^{\prime} \\
\mathrm{E}=125^{\circ} 53,505^{\prime}\end{array}$ & $\begin{array}{c}\text { Udept } \\
\text { (Kambisol) }\end{array}$ & 15 & 30 & Perbukitan & Lembar & Sedang \\
\hline 5 & $\begin{array}{l}\mathrm{S}=02^{\circ} 01,665^{\prime} \\
\mathrm{E}=125^{\circ} 52,257^{\prime}\end{array}$ & $\begin{array}{c}\text { Udept } \\
\text { (Kambisol) }\end{array}$ & +20 & 30 & Perbukitan & Lembar & Sedang \\
\hline 6 & $\begin{array}{l}\mathrm{S}=02^{\circ} 02,231^{\prime} \\
\mathrm{E}=125^{\circ} 52,085^{\prime}\end{array}$ & $\begin{array}{c}\text { Udept } \\
\text { (Kambisol) }\end{array}$ & $\begin{array}{l}+20 \\
-20 \\
\end{array}$ & 40 & Perbukitan & Lembar & Sedang \\
\hline 7 & $\begin{array}{l}\mathrm{S}=02^{\circ} 02,294^{\prime} \\
\mathrm{E}=125^{\circ} 52,040^{\prime}\end{array}$ & $\begin{array}{c}\text { Udept } \\
\text { (Kambisol) }\end{array}$ & +15 & 40 & Perbukitan & Lembar & Sedang \\
\hline 8 & $\begin{array}{l}\mathrm{S}=02^{\circ} 02,858^{\prime} \\
\mathrm{E}=125^{\circ} 51,828^{\prime}\end{array}$ & $\begin{array}{c}\text { Aquent } \\
\text { (Gleisol) }\end{array}$ & 1 & $>50$ & Dataran & Tidak & Ringan \\
\hline
\end{tabular}


Dari hasil analisis pada Tabel 7-9, ditemukan bahwa pada Ruas Jalan Sanana-Manaf $(31 \mathrm{~km})$, bahaya longsoran tergolong ringan, sedangkan pada Ruas Jalan Sanana-Polnea $(12,05 \mathrm{~km})$ dan Ruas Jalan PolneaMatufa $(13 \mathrm{~km})$, bahaya longsoran tebing jalan tergolong ringan sampai sedang. Pada lahan perbukitan dengan jenis tanah Kambisol umumnya kelas bahaya longsoran tergolong sedang. Namun pemotongan lereng untuk pembangunan ruas-ruas jalan ini, akan meningkatkan potensi bencana longsoran menjadi kelas tinggi.

Kondisi pulau kecil dengan topografi bukit dan gunung yang mendominasi, menyebabkan pembanguan dan atau pengembangan ruas jalan selalu berhadapan dengan konsekuensi pemotongan badan bukit atau gunung untuk ruas jalan yang dibangun sehingga potensi longsoran semakin tinggi akibat stabilitas lereng yang makin rendah. Sementara itu pada pembangunan jalan di Pulau Sanana, ditemukan bahwa ruas jalan Sanana-Manaf didominasi oleh fisiografi dataran pantai dengan kelerengan antara 0-5\% (datar-landai/ berombak); ruas jalan Sanana-Polnea dan PolneaMalbufa berada pada fisografi dataran dan perbukitan rendah dengan kelerengan antara $0-25 \%$ (datarbergelombang). Pada setiap lokasi perbukitan, secara potensial memiliki kerawanan longsor sedang yang berubah menjadi tinggi akibat pemotongan badan bukit untuk pembangunan ruas jalan

Sekalipun demikian, dengan sudut pemotongan lereng yang agak landai, dan adanya pembangunan bangunan/struktur penahan, dapat meningkatkan stabilitas lereng yang sempat menjadi sangat rendah (bahaya longsor tinggi) saat awal pemotongan lereng dan dengan begitu dapat mencegah longsoran yang mungkin terjadi terutama di musim penghujan. Hal ini sesuai pernyataan Theresia et al. (2011) bahwa untuk menanggulangi lereng yang tidak stabil di antaranya dengan cara menguragi gaya dorong dengan cara melandaikan sudut lereng dan memotong bagian atas lereng yang berada pada bidang longsor. Untuk meningkatkan gaya tahanan lereng dapat dilakukan dengan cara menimbun tanah dengan nilai kohesi yang memadai pada bagian kaki lereng dan memberikan perkuatan struktur.

Kondisi penggunaan lahan yang berada di atas lereng bukit yang dipotong berupa semak belukar harus dipertahankan untuk menghidari terbentuknya erosi alur dan parit yang dapat meningkatkan ancaman terjadinya longsoran yang dapat mengganggu kelancaran arus lalu lintas atau bahkan menimbulkan bencana bagi para pengguna jalan. Untuk meningkatkan stabilitas lereng perlu dilakukan penanaman tanaman konservasi yang berakar dalam sehingga perakarannya dapat bertindak sebagai stabilisator lereng yang dapat mencegah pergerakan massa tanah.

\section{KESIMPULAN}

1. Pada ruas jalan Sanana-Manaf sepanjang $31 \mathrm{~km}$, dengan fisiografi relative datar, bahaya longsoran tergolong ringan, sedangkan pada ruas jalan Sanana-Polnea sepanjang 12,05 km dan ruas jalan Polnea-Matufa sepanjang $13 \mathrm{~km}$, bahaya longsoran tebing jalan tergolong ringan sampai sedang.

2. Pada Ruas Jalan Polnea-Matufa yang didominasi oleh daerah perbukitan, telah meningkatkan ancaman longsoran yang makin tinggi karena tingkat stabilitas lereng yang makin menurun akibat pemotongan badan bukit untuk pembuatan jalan.

3. Sudut pemotongan lereng yang agak landai, dan adanya pembangunan struktur penahan, serta upaya mempertahankan kondisi penggunaan lahan di atas lereng serta pengayaan dengan tanaman-tanaman konservasi, dapat meningkatkan stabilitas lereng dan dengan begitu dapat mencegah longsoran yang mungkin terjadi terutama di musim penghujan

\section{DAFTAR PUSTAKA}

Badan Penelitian Dan Pengembangan Pertanian Departemen Pertanian. 2007. Petunjuk Teknis Teknologi Pengendalian Longsor. Balai Besar Litbang Sumberdaya Lahan Pertanian. Badan Penelitian Dan Pengembangan Pertanian Departemen Pertanian

Permentan No. 47/Permentan/OT.140/10/2006 Tentang Pedoman Umum Budidaya Pertanian Pada Lahan Pegunungan. Kementan RI, Jakarta.

Setiadi, E. 2006. Pengaruh Pembangunan Infrastruktur Dasar Terhadap Pertumbuhan Ekonomi Regional Indonesia (8 Provinsi di Sumatera). FEUI, Jakarta.

Sukresno, R.N. Adi, dan Wardoyo. 2004. Hubungan Sifat-Sifat Hujan Terhadap Kepekaan Tanah Longsor Di Kebumen. Prosiding Ekspose BP2TPDAS-IBB Surakarta Kebumen, 3 Agustus 2004

Sukisno, dan S.N. Muin. 2012. Prediksi Daerah Rawan Longsor di Kabupaten Kepahiang dengan Menggunakan SIG. Makalah dalam Seminar Nasional dalam Rangka Fakultas Pertanian Universitas Bengkulu 12 September 2012 dengan Tema: Menuju Pertanian yang Berdaulat.

Theresia, A., S. Wulandari, dan Baryanto. 2011. Analisis stabilitas lereng dan rancang bangun penahan tanah dengan pemrograman $\mathrm{C}++$ (Studi kasus: perencanaan jalan di lereng bayah, provinsi banten). Proceeding PESAT (Psikologi, ekonomi, Sastra, Arsitektur \& Sipil) Universitas Gunadarma - Depok 18-19 Oktober 2011 Vol.4 Oktober 2011.

Warsilan dan A. Noor. 2015. Peranan infrastruktur terhadap pertumbuhan ekonomi dan implikasi pada kebijakan pembangunan di Kota Samarinda. MIMBAR 31: 359-366. 